\title{
Penerapan Metode Eklektik Pada Pembelajaran Bahasa Arab Siswa Kelas VI SDIT Anak Sholeh Mataram
}

Oleh:

Ayatullah

\begin{abstract}
Abstrak: Tujuan penelitian ini adalah untuk mengetahui peran guru bahasa arab dalam menerapkan metode eklektik pada siswa kelas VI SDIT anak sholeh Mataram. Penelitian ini mengunakan pendekatan kualitatif. Untuk pengumpulan data menggunakan metode observasi, interview (wawancara) dan dokumentasi. Sedangkan untuk analisisnya, penulis mengunakan teknik analisis deskriptif kualitatif, yaitu berupa data-data yang tertulis atau lisan dari orang dan pengamatan kegiatan pembelajaran sehingga dalam hal ini penulis berupaya mengadakan penelitian yang bersifat mengambarkan secara menyeluruh tentang keadaan yang sebenarnya. Hasil penelitian ini menunjukkan bahwa penerapan metode eklektik dalam pembelajaran Bahasa Arab digunakan guru untuk mempermudah proses belajar-mengajar didalam kelas. Selain itu juga, metode eklektik dapat menggambarkan variasi metode mengajar bahasa Arab yang lebih efektif, sehingga siswa tidak cepat bosan dalam menerima materi yang diajarkan.
\end{abstract}

Kata Kunci: Penerapan, dan Metode Eklektik

\begin{abstract}
The purpose of this study was to determine the role of the Arabic language teachers in applying the eclectic method in class VI SDIT Mataram pious child. This study uses a qualitative approach. To collect data using the method of observation, interviews (interviews) and documentation. As for the analysis, the author uses descriptive qualitative analysis techniques, namely the form of data that is written or spoken of observation and learning activities so that in this case the author seeks to conduct research that is both thorough portrait of the real situation. The results of this study indicate that the application of the eclectic method in teaching Arabic language teachers use to facilitate the teaching-learning process in the classroom. In addition, the eclectic method can depict a variety of teaching methods more effective Arabic language, so that students do not get bored in receiving the material being tanght.
\end{abstract}

Keyword: Implementation and Eclectic Method

\section{PENDAHULUAN}

Bahasa adalah alat komunikasi dan penghubung dalam pergaulan sehari-sehari, baik antara individu dengan individu, individu dengan kelompok dan kelompok dengan bangsa tertentu. Dengan bahasa manusia saling kenal mengenal satu sama lain antara masyarakat yang satu dengan masyarakat lainnya, suku yang satu dengan suku lainnya dan bangsa yang satu dengan bangsa lainnya.

Salah satu bahasa yang saya kenal dekat yaitu bahasaArab. Bahasa Arab merupakan Bahasaal-Qur'an dan menjadi salah satu alat komunikasi internasional. Oleh karena itu mempelajari bahasa Arab menjadi kebutuhan setiap orang khususnya 
umat islam. Bahasa Arab disamping berperan sebagai alat penghubung komunikasi antara sesama manusia, juga berperan sebagai alat penghubung komunikasi manusia kepada Allah SWT yang mana diimplementasikan dalam bentuk sholat, do'a-do'a, membaca al-Qur'an dan bahasa Arab juga dalam hal ini persis dinyatakan oleh Abdul Alim Ibrahim dalam buku Fuad Efendi “Bahwa bahasa Arab merupakan bahasa orang Arab dan sekaligus juga merupakan bahasa Islam.

Karena al-Qur'an diturunkan dalam bahasa Arab, maka kaidah-kaidah yang diperlukan dalam memahami al-Qur'an bersendi atas kaidah-kaidah Bahasa Arab, memahami asas-asasnya, merasakan uslub-uslubnya dan mengetahui rahasiarahasiannya. Sebagaimana dalam firman Allah SWT dalam Surat Ibrahim ayat 4.

Artinya: "Kami tidak mengutus seorang rasul pun, melainkan dengan bahasa kaumnya, supaya ia dapat memberi penjelasan dengan terang kepada mereka. Maka Allah menyesatkan siapa yang dia kehendaki, dan memberi petunjuk. kepada siapa yang dia kehendaki. Dan dialah Tuhan yang Maha Kuasa lagi Maba Bijaksana(Departemen Agama RI, 2007, 255).

(Qs. Ibrahim Ayat 4)

Dalam kegiatan belajar mengajar bahasaArab tidak terlepas dari partisipasi dari pendidik dan peserta didik. Sebab efektifnya suatu kegiatan belajar berkenaan dengan sejauh mana apa yang direncanakan terlaksana atau tercapai. Bila ada sepuluh jenis kegiatan yang kita rencanakan dan tercapai hanya lima kegiatan yang dapat dilaksanakan maka efektifitas kegiatan kita masih belum memadai dan efektif.

Dalam bidang pendidikan, efektifitas ini dapat saya tinjau dari dua segi: pertama efektifitas mengajar seorang guru terutama mencakup sejauh mana jenis-jenis kegiatan belajar mengajar yang direncanakan dapat dilaksanakan dengan baik. Kedua : efektifitas belajar murid terutama menyangkut sejauh mana tujuan-tujuan pelajaran yang diinginkan telah dapat dicapai melalui kegiatan belajar mengajar yang ditempuh.

Pembelajaran yang efektif adalah suatu upaya mengetahui berhasil tidaknya pelaksanaan pembelajaran, khususnya bahasa Arab baik dari segi proses maupun hasil. Maka peran guru tidak cukup sebagai pengajar saja. Upaya yang dapat dilakukan adalah berupa pengadaan buku pedoman, buku-buku karya ilmiah pusat latihan, laboratorium bahasa, media-media yang menyajikan bahasaArab yang mudah atau gamblang dan metodologis.

Pada dasarnya, untuk mempelajari bahasa Arab pada tingkat pemula yang terdiri dari peserta didik yang mempunyai latar belakang yang berbeda, seharusnya yang diutamakan adalah bagaimana cara berbahasa Arab yang baik dan benar, bukan teori-teori bahasa atau tata bahasa itu sendiri, karena mempelajari tata bahasa bukan tujuan dari pembelajaran bahasa, melainkan suatu sarana untuk dapat menggunakan bahasa yang benar dalam berkomunikasi.

Perkembangan dan pembaharuan serta hasil yang akan diraih dalam pembangunan bangsa sekarang ini tidak terlepas dari peran penting seorang guru. 'Yang dimaksud dengan peranialah pola tingkah laku tertentu yang merupakan ciriciri khas semua petugas dari pekerjaan atau jabatan tertentu.

Guru dewasa ini berkembang sesuai dengan fungsinya sebagai pembina untuk mencapai tujuan pendidikan. Seorang guru dituntut memahami betul komponenkomponen pendidikan yang benar-benar memiliki pengertian, pengetahuan, kemampuan serta kecekatan profesional yang tangguh. setiap pendidik yang telah dipersiapkan secara profesional harus mampu memahami dasar pengajaran, tujuan 
dan isi pengajaran, disamping itu guru juga dituntut menguasai berbagai metode dan pendekatan dalam proses pembelajaran. yang mana metode ini akan memberikan pengaruh atau dampak yang positip bagi peserta didik.

Dalam bukunya Ahmad Fuad Effendy yang berjudul metodologi pengajaran bahasaArab terdapat beberapametode yang digunakan oleh seorang guru dalam mengajar, yang mana metode itu adalah metode Gramatika-Terjemah (al-tharíqah alqawaîd wat-tarjamab), metode langsung (al-tharîah al-mubâsyirab), metode membaca(altharîqah al-qirâab), metode audiolingual (al-tharîah al-sam'iyyah al-syafahiyah), metode komunikatif (al-thariqah al-ittsha'iyyah), metode eklektik (al-tharíqah al-intiqâiyyah).

Dalam hal ini metode ini tidak dapat dikatakan mana yang paling baik, karena setiap metode memiliki landasan-landasan teoritis dan empiris. secara skeptis bisa dikatakan bahwa tampaknya semua metode ada baiknya. Pada kenyataannya, hingga saat ini, tidak ada metode (yang paling kuno sekalipun) yang mati atau ditinggalkan sama sekali, dan tidak ada pula metode yang paling dominan sepanjang waktu atau disemua tempat. ini terjadi karena pemilihan suatu metode ditentukan oleh banyak faktor, antaralain tujuan pengajaran, latar belakang bahasa pelajar, usia pelajar waktu yang tersedia, kesiapan guru dan faktor sosio-kultural.

Guru bahasa Arab memiliki perananyang sangat penting dalam menentukan kualitas pembelajaran yang dilaksanakannya. Oleh karena itu,guru bahasa Arab harus memikirkan dan membuat perencanaan secara seksama dalam meningkatkan kesempatan belajar bagi siswanya dan memperbaiki kualitas pengajarannya. Hal ini menuntut perubahan-perubahan dalam pengorganisasian kelas, penggunaan metode mengajar, strategi belajar mengajar maupun sikap dan karakteristik guru dalam mengelola proses belajar mengajar.

Metode yang digunakan oleh guru sangat berpengaruh dalam proses belajar mengajar, karena dengan metode yang digunakan, akan mudah menarik minat belajar siswa apalagi untuk belajar bahasa Arab. Dalammenggunakan metode untuk mengajar guru harus mengguasai dan paham,karena dengan metode yang menarik dan bervariasi siswa akan mudah tertarik dan senang untuk belajar. Apalagi siswa masih di tingkat SD. Jadi seorang guru harus paham dalam menggunakan metode yang akan di berikan kepada siswa dalam proses belajar mengajar.

Melihat dari kondisi siswa yang masih ditingkat pemula, dengan demikian, maka seorang guru harus pandai menggunakan metode dalam pembelajaran sehingga siswa bergairah dalam belajar bahasa Arab. Dari pemaparan, maka peneliti tertarik untuk mengadakan penelitian 'Bagaimana penerapan metode eklektik pada pembelajaran bahasa arab siswa kelas VI di SDIT Anak Sholeh Mataram.

\section{PEMBAHASAN}

\section{Metode Eklektik (Al-Thariqah Al-Intiqa'iyyah)}

Sebelum penulis menjelaskan lebih lanjut tentang metode eklektik, penulis ingin menjelaskan terlebih dahulu pengertian metode secara etimologi dan terminologi.

a. Metode secara etimologi 
Metode dalam bahasa Arab, dikenal dengan istilh trariqah yang berarti langkahlangkah strategis yang dipersiapkan untuk melakukan suatu pekerjaan. Bila dihubungkan dengan pendidikan maka metode itu harus diwujudkan dalam proses pendidikan, dalam rangka mengembangkan sikap mental dan kepribadian agar peserta didik menerima pelajaran dengan mudah, efektif dan dapat direncana dengan baik.

b. Metode secara terminologi

Para ahli mendefinisikan metode sebagai berikut:

1. Hasan Langgulung mendifinisikan bahwa metode adalah cara atau jalan yang harus dilalui untuk mencapai tujuan pendidikan.

2. Abd. Al-Rahman Ghunaimah mendifiniskan bahwa metode adalah cara-cara praktis dalam mencapai tujuan penhgajaran.

3. Ahamd Tafsir mendifinisikan bahwa metode mengajar adalah cara yang paling tepat dan cepat dalam mengajarkan mata pelajaran.

4. Abdul al-Raziq yang di kutip oleh Acep Hermawan mendifinisikan bahwa metode adalah tingkat perencanaan program yang bersifat menyeluruh yang berhubungan erat dengan langkah-langkah penyampaian materi pelajaran secara prosedural, tidak saling bertentangan dengan pendekatan tertentu. dengan kata lain metode adalah langkah-langkah umum tentang penerapan teori-teori yang ada pada pendekatan tertentu. Lebih lanjut di jelaskan, dalam tingkatan ini diadakan pilihanpilihan tentang keterampilan khusus mana yang harus diajarkan, materi-materi apa yang harus disampaikan dan bagaimana urutannya.

Berdasarkan beberapa difinisi diatas dapat disimpulkan bahwa metode adalah seperangkat cara, dan jalan yang digunakan oleh ppendidik dalam proses pembelajaran agar peserta didik dapat mencapai tujuan pembelajaran atau menguasai kompetensi tertentu yang dirumuskan dalam silabi mata pelajaran.

Metode eklektik (al-thariqah al-intiqa'iyyah)adalah metode yang merupkan pemilihan dan penggabungan. pemilihan dan penggabungan yang di maksud metode ini bukan menggabungkan metode yang ada, tetapi lebih bersifat " tambal sulam" artinya setiap metode dipandang dapat mengatasi kekurangan metode tertentu dengan memanfaatkan kelebihan metode lain. Metode ini adalah metode yang menggabungkan beberapa metode sesuai kebutuhan atas dasar pertimbangan tujuan pembelajaran, sifat materi pelajaran, kemampuan pelajar, bahkan kondisi guru.

Metode eklektik atau metode gabungan (al-thariqah al-intiqa'iyyah/eclectic method) merupakan kreativitas para pengajar bahasa arabuntuk mengefektifkan proses belajar mengajar bahasa arab. Metode ini juga sekaligus memberikan kebebasan kepada merekauntuk menciptakan variasi metode.

Sebagaimana metode-metode lainnya, metode eklektik memiliki asumsi-asumsi atau dasar dijadikan pijakannya. Menurut al-Khuli yang di kutif oleh Acep, ada 6( enam) hal yang menjadi pijakan metode eklektik, sebagai berikut:

1) Setiap metode pengajaran bahasa asing memiliki kelebihan. kelebihan ini bisa dimanfaatkan dalam pengajaran bahasa asing.

2) Tidak ada metode yang sempurna, dan juga tidak ada metode yang jelek, tetapi semuannya memiliki kekuatan dan kelemahan. Kekuatan metode tertentu bisa jadi dapat mengatasi kelemahan metode tertentu.

3) Setiap metode memiliki latar belakang, karakteristik, dasar pikiran, dan peruntukan yang berbeda, bahkan bisa jadi suatu metode muncul karena menolak metode 
sebelumnya, Jika metode-metode tersebut digabungkan, maka akan menjadi sebuah kolaborasi yang saling menyempurnakan.

4) Tidak ada satu metode pun yang sesuai dengan semua tujuan, semua guru, semua siswa, dan semua program pengajaran.

5) Hal yang terpenting dalam mengajar adalah memberi perhatian kepada para pelajar dan kebutuhannya, bukan menguasai metode tanpa didasarkan kepada para pelajar dan kebutuhannya.

6) Setiap gurubahasa asing di beri kebebasan untuk menggunakan langkah-langkah atau teknik-teknik dalam menggunakan metode pelajaran yang sesuai dengan kemampuannya.

\section{Langkah-langkah Penggunaan Metode Eklektik (Al-Thariqah Al- Intiqa'iyyah)}

Menggunakan metode eklektik (Al-Thariqah Al-Intiqa'iyyah) ini dalam pengajaran bahasa asing adalah memanfaatkan kelebihan metode tertentu untuk mengatasi kekurangan metode lain. Misalnya seorang guru bermaksud untuk melatihkan keterampilan berbicara sekaligus melatih teks bacaan dan kaidah gramatika, maka guru dapat mengklaborasikan metode langsung (al-trariqab almubasyirah) dengan metode kaidah dan tarjamab(al-trariqah al-qawa'id wal-tarjamah) ditambah dengan metode membaca (al-trariqah al-qira'ah).

Terlihat di sini bahwa kegiatan belajar mengajar akan menjadi sangat vareatif, tidak terfukus pada satu kegiatan. Maka pengabungan ini di harapkan akan membuat kegiatan ini memacu motivasi para pelajar dalam belajar bahasa asing. Seperti metode lain, langkah yang bisa digunakan untuk menggunakan metode ini fleksibel. misalnya langkah yang ditempuh oleh guru adalah sebagai berikut: Pertama pendahuluan, sebagaimana metode lain.

Kedua memberikan materi berupa dialog-dialog pendek yang rilek, dengan tema kegiatan sehari-hari secara berulang-ulang. Materi ini mula-mula disajikan secara lisan dengan gerakan-gerakan, isyarat-isyarat, dramatisasi-dramatisasi, atau gambar-gambar. Tiga para pelajar diarahkan untuk disiplin menyimak dialog-dialog tersebut, lalu menirukan dialog-dialog yang disajikan sampai lancar. Empat para pelajar dibimbing menerapkan dialog-dialog itu dengan teman-temannya secara bergiliran.

Lima setelah lancar menerapkan dialog-dialog yang telah dipelajari, mereka diberi teks bacaan yang temanya berkaitan dengan dialog-dialog tadi. Selanjutnya guru memberi contoh cara membaca yang baik dan benar, diikuti oleh para pelajar secara berulang-ulang. Keenam jika terdapat kosakata yang sulit, guru memaknainya mulamula dengan isyarat, atau gerakan, atau gambar, atau lainnya. Jika tidak mungkin dengan ini semua, guru menerjemahkannya ke dalam bahasa pelajar. Ketujuh guru mengenalkan beberapa struktur yang penting dalam teks bacaan, lalu membahasnya seperlunya.

Delapan guru menyuruh para pelajar menelaah bacaan, lalu mendiskusikan isinya. Sembilan sebagai penutup, jika diperlukan, evaluasi akhir berupa pertanyaanpertanyaan tentang isi bacaan yang telah dibahas. Pelaksanaannya bisa saja secara individual atau kelompok, sesui dengan situasi dan kondisi. Jika tidak memungkinkan karena waktu, misalnya, guru dapat menyajikannya berupa tugas yang harus dikerjakan di rumah masing-msing murid/siswa. 


\section{Kelebihan dan Kekurangan Metode Eklektik (A1-Thariqah A1-Intiqa'iyyah)}

Adapun kelebihan pengajaran bahasa dengan menggunakan metode eklektik adalah sebagai berikut :

1) Kegiatannya lebih variatif atau bersifat variasi dalam pengajaran

2) Kemampuan para pelajar dalam menggunakan bahasa asing dipandang lebih merata

3) Guru lebih bersemangat dan energik dalam mengajar

4) Siswa tidak cepat bosan dalam belajar

Sedangkan kekurangan metode eklektik ini dalam pengajaran pengajaran bahasa adalah :

1) Menggunakan metode eklektik, nampaknya akan bermasalah dengan kesediaan guru dan siswa, dan alokasi waktu.

2) Dalam menggunakan metode eklektik, belum tentu semua guru sanggup melakukan serangkaian kegiatan yang begitu banyak dan bervariasi.

3) Menuntut adanya guru yang segala bisa dan energik.

4) Dikhawatirkan kegiatan belajar yang begitu banyak akan membuat siswa kejenuhan dalam belajar, apalagi materi dibawakan secara monoton. Dibutuhkan waktu yang relatife lebih banyak.

\section{Metode Penelitian}

Metode penelitian pada dasarnya merupakan cara ilmiah untuk mendapatkan data dengan tujuan dan keguanaan tertentu. Cara ilmiah berarti kegiatan penelitian itu didasarkan pada ciri-ciri keilmuan, yaitu rasional, empiris, dan sistematis. Adapun penelitian ini merupakan penelitian yang berangkat dari sebuah fenomena pada Peran Guru Bahasa Arab dalam menerapkan Metode Eklektik di SDIT Anak Sholeh Mataram, yang mana fenomena terkait dengan persoalan Peran Guru dalam Menerapkan Metode Eklektik pada Pembelajaran Bahasa Arab yang di lakukan guru Bahasa Arab yang ada di SDITAnak Sholeh Mataram. Maka dalam penelitian ini, peneliti akan menggunakan pendekatan kualitatif sebagai salah satu metode penelitian yang sangat prosedural dan menghasilkan data deskriptif berupa kata-kata tertulis atau lisan dari orang-orang dan perilaku yang dapat diamati.

\section{Kehadiran peneliti}

Peneliti akan melakukan penelitian ini secara intensif dan selalu hadir sewaktu pembelajaran tersebut berlangsung. Karena kehadiran peneliti sebagai pengamat langsung maupun peneliti sebagai pengamat langsung maupun tidak langsung akan memberikan konstribusi yang jelas terhadap validitasnya sebuah data yang diperoleh di lokasi penelitian. Berdasarkan hal tersebut, maka akan menjadi suatu keharusan bagi peneliti untuk terus ada di lokasi penelitian secara intensif ketika proses pmbelajaran berlangsung.

\section{Lokasi Penelitian}


Penelitian ini berlokasi di SDITAnak Sholeh Mataram lokasi penelitian ini jarang sekali peneliti yang meneliti di tempat ini, paling menariknya menurut peneliti adalah di tempat itu tidak hanya ada pembelajaran bahasa Arab, akan tetapi di sana ada pembelajaran al-Qur'an sekaligus di sana diterapkan menghafal bagi peserta didik, dengan adanya pembelajaran seperti itu, peran guru sangat penting dalam pembelajaran.

\section{Sumber Data}

Adapun sumber data dalam penelitian ini adalah dewan guru, siswa dan siswi SDIT Anak Sholeh Mataram. Oleh karena itu, peneliti menggunakan sumber data berupa orang. Dengan kata lain, responden adalah orang yang merespon atau memberi jawaban kepada peneliti dalam proses mendapatkan data penelitian. Dalam hal ini, responden dalam penelitian ini adalah Dewan Guru dan Siswa - Siswi SDIT Anak Sholeh Mataram.

\section{Prosedur Pengumpulan Data}

Peneliti akan menggunakan metode yang lazimnya digunakan dalam penelitian kualitatif, yaitu sebagai berikut:

a. Observasi

Observasi secara umum dapat dibedakan menjadi dua bagian yaitu: 1). Observasi non sistematis, yaitu dilakukan oleh pengamat dengan tidak menggunakan instrumen pengamatan. 2). Observasi sistematis, yaitu dilakukan oleh pengamat dengan menggunakan pedoman sebagai instrumen pengamatan.

b. Wawancara

wawancara adalah percakapan dengan maksud tertentu. Percakapan itu dilakukan oleh dua pihak, yaitu pewawancara (interviewer) yang mengajukan pertanyaan dan terwawancara (interviewee) yang memberikan jawaban atas pertanyaan itu.

c. Dokumentasi.

Dokumentasi, peneliti gunakan untuk mengumpulkan data sekunder, data tertulis yang memberikan informasi yang dibutuhkan oleh peneliti yakni mengenai lokasi penelitian yang meliputi: profil dan letak geografis SDIT Anak Sholeh Mataram, sejarah berdirinya visi dan misi, keadaan guru, keadaan siswa, sarana dan prasarana, serta struktur organisasi yang ada di SDIT Anak Sholeh Mataram.

\section{Analisis Data.}

Dalam menganalisis data, peneliti menerapkan dua langkah yaitu: 1) Persiapan 2). Penerapan data sesuai dengan pendekatan penelitian mengingat penelitian ini datadata kualitatif, maka penerapan analisis data secara deskriptif, yaitu analisis yang berangkat dari kasus atau peristiwa yang khusus kemudian melakukan generalisasi dengan mengambil kesimpulan yang sifatnya umum.

\section{Validitas Data dan Temuan}

Untuk mendapatkan keabsahan (trustworthiness) data di perlukan teknik pemeriksaan. Pelaksanaan teknik pemeriksaan di dasarkan atas sejumlah kriteria tertentu. Ada empat kriteria yang di gunakan yaitu derajat kepercayaan (Credibility), 
keteralihan (transferability), kebergantungan (Dependability) dan kepastian (Confirmability).

\section{PAPARAN DATA DAN TEMUAN}

\section{Sejarah Berdirinya SDIT Anak Sholeh Mataram}

SDIT Anak Sholeh adalah merupakan salah satu lembaga pendidikan formal yang menyelenggarakan pendidikan dan pengajaran formal yang Islami. SDIT Anak Sholeh Mataram juga adalah sekolah dasar yang mengembangkan pembelajaran yang berbeda dari sekolah dasar yang lainnya. Dan SDIT Anak Sholeh Mataram dikelola oleh Yayasan Pendidikan Islam Terpadu (TPIT) Ibnu Abbas. Ketua Dewan Pembina Ust. H. Muharror Mahfuz dan ketua Yayasan adalah Utman Rifqi, SP.

YPIT Ibnu Abbas memiliki consent yang cukup kuat untuk mengembangkan pendidikan di NTB khususnya di Mataram dengan pendekatan yang sesuai dengan perkembangan dunia pendidikan yang tidak terlepas dari penanaman nilai-nilai agama sejak dini.

SDIT Anak Sholeh adalah sekolah dasar yang setara dengan SD dan MI. Kehadiran SDIT ini tidak hanya ditujukan untuk mengembangkan potensi akademik semata tetapi juga melejitkan potensi-potensi kepemimpinan, kewirausahaan dan kemandirian yang terbingkai dalam religiusitas, kedekatan dengan nilai agama. selain itu SDIT Anak Sholeh Mataram mempunyai program unggulan sebagai berikut : a) Tahsin Qur'an metode UMMI. b). Tahfidz qur'an juz 29-39. c) Sholat Dhuha berjamaah. d)Romadhon Ceria. e) Qurban peduli. f) Market Day g)Garden Day h) Kunjungan Ilmiah i)Renang j)Kunjungan Perpustakaan k)Outbond. 1)Pelatihan orangtua efektif $\mathrm{m}$ )Student Day.

Pada tahun 2006-2007, SDITAnak Sholeh Mataram tersebut dibuka dan setelah 2 tahun menyewa gedung untuk proses belajar-mengajar dan kegiatan akademik lainnya. Dan jumlah murid 28 orang pada saat itu. Sedangkan yang menjadi Direktur/Kepsek pada waktu itu adalah Bapak Muazzar. Beliau menjabat menjadi Direktur/Kepsek selama 3 tahun dan siswa yang sekolah di SDITAnak Sholeh Mataram adalah rata-rata dari kalangan menengah ke atas seperti dosen, guru, perawat dan pengusaha dll. Dan siswa yang sekolah di SDIT asalnya lebih dominan dari kota Mataram, Lotim, Loteng, dan sekitarnya juga dari Gerung dan Kediri Lombok Barat.

SDIT Anak Sholeh Mataram adalah salah satu sekolah dasar yang berada di kecamatan mataram yang berlokasi di Desa/Kelurahan Pagesangan baru.Berikut nama-nama yang pernah menjabat sebagai Direktur/Kepsek SDIT Anak Sholeh Mataram dari tahun 2006-2014 adalah sebagai berikut:

1. Muazzar dari tahun 2006 sampai tahun 2008

2. Wahidah, SE dari tahun 2008 sampai sekarang.

\section{Letak Geografis}

Pada tahun ajaran 2008/2009 SDIT menempati lokasi baru di Jl. Merdeka Raya Merdeka VII atau Gg. Anak Sholeh School Pagesangan Mataram.Lokasi baru ini adalah milik sendiri SDIT Anak Sholeh Mataram, dan disetting dalam bentuk sekolah alam, yaitu yang terdiri dari ruang-ruang kelas terbuka (brugak), aula / ruang pertemuan, ruang guru, wc dan kantin. SDIT Anak Sholeh Mataram menempati lahan seluas 3 hektar dengan batas wilayah sebagai berikut. 

a. Sebelah Utara
: Perumahan Penduduk
b. Sebelah Selatan
: Persawahan
c. Sebelah Timur
: Pondok Tahfiz
d. Sebelah Barat
: Perumahan Penduduk.

\section{Visi Misi dan Tujuan Sekolah}

a. Visi :

Membentuk generasi Cerdas, Kreatif, Bertaqwa

b. Misi :

1) Mewujudkan budaya sekolah yang religius dalam mencetak siswa yang memiliki aqidah dan akhlak yang benar serta kesadaran beribadah yang tinggi.

2) Mewujudkan proses pembelajaran yang efektif sehingga siswa mencapai ketuntasan belajar dan diterima di sekolah favorit.

3) Merealisasikan kegiatan siswa yang variatif dalam membentuk kemandirian, kreatitivitas dan jiwa kepemimpinan.

4) Mewujudkan partnership rumah-sekolah yang kokoh dan berkesinambungan dalam membangun karakter dan prestasi siswa

5) Mewujudkan dan membangun manajemen sekolah yang handal

6) Mewujudkan lingkungan sekolah yang bersih, nyaman, sehat dan bersahabat

7) Mewujudkan sumber daya pendidik dan kependidikan yang kompeten dan professional

b. Tujuan

Menjadi sekolah berkarakter religius, pembelajar, mandiri, kreatif dan berjiwa kepemimpinan didukung tenaga pendidik dan manajemen sekolah yang professional dalam jalinan partnership sekolah-rumah yang kokoh dan berkesinambungan.

\section{Keadaan Guru dan Siswa}

a. Kondisi guru

SDIT Anak Sholeh Mataram memiliki Guru /Karyawan tetap yayasan sebanyak 25 orang yaitu: terdiri dari 1 Direktur/Kepsek, 3 Waka, 1 Guru Mapel, 1 Guru Olahraga, $1 \mathrm{Tu}$ dan 1 Petugas Perpustakaan. SDIT Anak Sholeh Mataram memiliki 27 Guru Tetap Sekolah, 2 Guru Tidak Tetap, 10 Karyawan Sekolah yang terdiri dari 1 TU, 1 Penjaga Malam, 1 Petugas Satpam, 1 Petugas Kantin, 2 Petugas Kebersihan dan 4 Penjaga Anak.

b. Kondisi Siswa

SDIT ANAK SHOLEH MATARAM dari tahun pelajaran 2006/2007 sebanyak 28 siswa dan pada tahun 2007/2008 sebanyak 80 orang siswa dan pada tahun $2008 / 2009$ siswa yang masuk sebanyak 167 . pada tahun $2009 / 2010$ siswa yang masuk sebanyak 267. dan pada tahun 2010/2011 sebanyak 371dan tahun 2011/2012 sebanyak 490 dan pada tahun 2012/2013 sebanyak 626 dan tahun 2013-2014 ini sebanyak 677 .

\section{Sarana dan Prasarana}


Dalam menunjang tercapainya pelaksanaan pendidikan yang diharapkan, penyediaan sarana dan prasarana pendukung proses belajar mengajar sangat diperlukan, karena sarana dan prasarana merupakan salah satu faktor yang menjadi tolok ukur keberhasilan kegiatan belajar sehingga tercapai hasil yang diharapkan, untuk itu SDIT Anak Sholeh Mataram telah menyediakan sarana dan prasarana pendidikan.

\section{Penerapan Metode Eklektik (Al-Thariqah Al-Intiqa'iyyah) Pada Pembelajaran Bahasa Arab Siswa Kelas VI SDIT Anak Sholeh Mataram.}

Salah satu komponen penting dalam pendidikan adalah guru. Guru dalam konteks pendidikan mempunyai peranan yang besar. Hal ini disebabkan gurulah yang berada di barisan terdepan dalam pelaksanaan pendidikan. Gurulah yang langsung berhadapan dengan peserta didik untuk mentransfer ilmu pengetahuan dan teknologi sekaligus mendidik dengan nilai-nilai positif melalui bimbingan dan keteladanan. Dengan demikian guru mempunyai misi dan tugas yang berat, namun mulia dalam mengantarkan tunas-tunas bangsa ke puncak cita-cita.

Dalam pelaksanaan kegiatan belajar mengajar di SDIT Anak Sholeh Mataram terbilang cukup baik. Hal ini menurut peneliti disebabkan karena siswa-siswa SDIT Anak Sholeh Mataram sangat aktif dalam kelas untuk kegiatan pembelajaran khususnya pembelajaran bahasa Arab.

Kurikulum yang digunakan di madrasah ini adalah Kurikulum Tingkat Satuan Pendidikan (KTSP). Hal ini tentunya menuntut setiap guru untuk menyusun perangkatpembelajaran sebelum mengajar.Kurikulum Tingkat Satuan Pendidikan Sekolah Dasar SD Islam Terpadu Anak Sholeh dikembangkan sebagai perwujudan dari kurikulum pendidikan dasar dan menengah. Kurikulum ini disusun oleh satu tim penyusun yang terdiri atas unsur sekolah dan Komite Sekolah dibawah koordinasi dan supervisi YPIT Ibnu Abbas Mataram yang didasarkan pada prinsip-prinsip sebagai berikut:

1. Berpusat pada potensi, perkembangan, kebutuhan, dan kepentingan peserta didik dan lingkungannya

2. Beragam dan terpadu

3. Tanggap terhadap perkembangan ilmu pengetahuan, teknologi dan seni

4. Relevan dengan kebutuhan kehidupan

5. Menyeluruh dan berkesinambungan

6. Belajar sepanjang hayat dan

7. Seimbang antara kepentingan nasional dan kepentingan daerah.

Dari prinsip-prinsip diatas lalu dijabarkan sesuai dengan visi dan misi yang ingin dikembangkan oleh SD Islam Terpadu Anak Sholeh Mataram, sehingga kurikulum tersebut diarahkan menjadi :

1. Kurikulum yang mengembangkan kecerdasan (Bahasa, Sains, logika matematika).

2. Kurikulum yang mengembangkan kreativitas (Outbound, pendidikan jasmani, kewirausahaan, seni, kepanduan dan sosial kemasyarakatan).

3. Kurikulum yang mengembangkan ketaqwaan (Keimanan, ibadah, Al-Quran, sikap hidup, dan integrasi dengan alam.)

Pada akhirnya kurikulum ini tetap hanya sebuah dokumen, yang akan menjadikenyataan apabila terlaksana di lapangan baik dalam kelas maupun di luar 
kelas. Proses pembelajaran hendaknya berlangsung secara efektif yang mampu membangkitkan aktivitas dan kreativitas anak serta mampu menggali dan membangkitkan multi kecerdasannya baik kecerdasan spiritual, emosional, intetektual serta kecerdasan fisik. Dalam hal ini para pelaksana kurikulumlah (guru) yang akan membumikan kurikulum ini dalam proses pembelajarannya.

Para pendidik juga hendaknya mampu menciptakan pembelajaran yang menyenangkan dan mengasyikkan bagi anak, sehingga anak betah di sekolah. Atas dasar kenyataan tersebut, maka pembelajaran di sekolah dasar hendaknya bersifat mendidik, mencerdaskan, membangkitkan aktivitas dan kreativitas anak, efektif, demokratis, menantang, menyenangkan, dan mengasyikkan. Dengan spirit seperti itulah kurikulum ini akan menjadi pedoman yang dinamis bagi penyelenggaraan pendidikan dan pengajaran di Sekolah Dasar Islam Terpadu (SDIT) Anak Sholeh Mataram.

Berdasarkan hasil observasi awal yang dilakukan peneliti, dalam proses pembelajaran yang selama ini diterapkan oleh guru di SDIT Anak Sholeh Mataram, dalam menyampaikan materi ajar pada mata pelajaran bahasa Arab di kelas VI yaitu sebagai berikut:

Berdasarkan hasil observasi awal yang dilakukan peneliti, dalam proses pembelajaran yang selama ini diterapkan oleh guru di SDIT Anak Sholeh Mataram, dalam menyampaikan materi ajar pada mata pelajaran bahasa Arab di kelas VI yaitu sebagai berikut:Guru menuliskan materi di papan tulis kemudian menjelaskan materi dan peserta didik membaca materi yang akan diajarkan, sehinga peserta didik cepat menanggapi dan memahami penjelasan dari guru.

1. Peserta Didik diberikan waktu untuk menghapal materi yang sudah dijelaskan selama dua menit dan peserta didik dipanggil satu persatu sesuai urutan absen untuk menghapal materi yang sudah dijelaskan.

2. Guru melakukan tanya jawab dan memberikan soal atau latihan kepada peserta didik dan yang dinilai dalam soal latihan itu adalah tulisan, kerapian dan ketepatan hurufnya kemudian setelah itu, guru memberikan peserta didik stimulus dengan membuat pertanyaan dan peserta didik menjawabnya.

3. Kemudian guru menceritakan kisah yang bernuansa Islami dan ada humornya untuk menyegarkan kepala peserta didik dan guru juga menyelipkan pesan-pesan moral kepada peserta didik.

Berdasarkan hasil observasi penulis selama berada di SDIT anak Sholeh Mataram yaitu peneliti melihat bahwa yang menunjang sebuah pembelajaran efektif dalam menerapkan metode eklektik adalah yaitu:

1. Guru profesional

2. Variasi metode mengajar

3. Suasana demokratis

4. Lingkungan yang kondusif

5. Sarana yang cukup menunjang

Untuk mencapai tujuan efektifitas, guru dalam penerapan metode eklektik, maka seorang guru perlu mengetahui dan memahami metode yang tepat dalam menyampaikan materi Bahasa Arab khususnya mata pelajaran Bahasa Arab dan metode yang dipergunakan dalam penyampaian suatu materi pelajaran tergantung pada tujuan materi, situasi dan kondisi. 
Metode eklektik dalam pembelajaran Bahasa Arab dipergunakan dalam rangka memberikan siswa kemudahan untuk belajar Bahasa Arab supaya materi yang dipelajarinya mudah di pahami oleh siswa dan dengan menggunakan metode eklektik siswa tidak akan cepat bosan belajar karena guru tidak terpaku dengan satu metode saja akan tetapi mempunyai banyak metode. Apabila guru hanya menggunakan satu metode dalam pembelajaran bahasa arab maka siswa akan cepat mengalami kebosanan dan sering juga siswa tidak memperhatikan guru dan mudah mengantuk apalagi siswa yang belajar bahasa arab masih dibangku SD.

Dalam pelaksanaan kegiatan belajar mengajar pada mata pelajaran bahasa arab di SDIT Anak Sholeh Mataram, guru menggunakan beberapa metode dalam mengajar, yaitu:

1. Metode ceramah

2. Metode tanya jawab

3. Metode kerja kelompok

4. Metode Pemberian Tugas

Berdasarkan hasil wawancara penulis dengan guru bahasa Arab Ilham Mahfudzdi SDIT Anak Sholeh Mataram terkait dengan peran guru dalam penerapan metode eklektik di kelas yaitu : Secara khusus di SDIT Anak Sholeh Mataram, guru menjalankan sistem pembelajaran yang aktif kepada siswa karena siswa itu bermacam-macam, bervariasi dan beraneka ragam karakter, jadi ada siswa yang daya serapnya rendah dan ada juga siswa yang daya serapnya bagus dan untuk mengatasi hal itu saya terlebih dahulu memberikan siswa motivasi dan permainan agar supaya seorang siswa itu menyenangi mata pelajaran yang saya sampaikan sehingga apabila seorang siswa merasa senang untuk mempelajarinya, maka minatnya untuk mempelajari hal tersebut akan semakin besar.

Dan kendala bagi saya untuk mengajar Bahasa Arab adalah kurangnya alokasi waktu, karena alokasi waktu untuk pelajaran bahasa Arab hanya 60 menit dan untuk mengatasi siswa yang daya serapnya rendah adalah sekolah mengadakan remedial di sekolah setiap hari jum'at dan juga saya selaku guru bahasa Arab mengadakan les privat bagi siswa yang mau belajar bahasa arab dan saya mengadakan itu di rumah. Untuk membuat siswa bisa Bahasa Arab itu maksimal siswa yang saya ajar ada 5 orang".

Dan penulis berhasil juga mewawancarai guru Al-Qur'an SDIT Anak Sholeh Mataram mengatakan sebagai berikut.Peran guru menurut saya adalah guru tidak hanya sekedar memberikan pelajaran saja akan tetapi guru tugasnya adalah sebagai pembimbing siswa untuk belajar dan guru juga tugasnya mengarahkan siswa agar supaya siswa tidak menerima pelajaran dari guru saja namun guru bertugas membimbing dan mengarahkan siswa untuk belajar aktif dan agar siswa juga ikut terlibat dalam pembelajaran itu sendiri.

Dan untuk metode, saya menggunakan metode campuran, karena kalau saya hanya menggunakan satu metode saja otomatis siswa akan cepat merasa bosan untuk belajar dan apalagi kita mengajar di bangku SD, untuk tidak membuat siswa merasa bosan dan jenuh seorang guru harus pandai-pandai menggunakan metode.

Berdasarkan hasil observasi secara langsung dari tiga kelas yaitu khususnya kelas VI di SDIT Anak Sholeh Mataram. Di SDIT anak sholeh mataram kelas VI ada tiga kelas dan masing-masing kelas terdapat siswa yang bagus daya serapnya dan terdapat juga siswa yang rendah daya serapnya dan tentang pelaksanaan 
pembelajaran, penulis melakukan observasi pada saat berlangsungnya proses belajar mengajar bidang study Bahasa Arab di kelas VI untuk mengetahui bagaimana pelaksanaannya.

Untuk lebih jelasnya penulisan paparan hasil observasi selama beberapa minggu terhadap metode yang di terapkan oleh guru bidang study, dalam hal ini penulis langsung melibatkan diri dalam kelas pada saat proses pelajaran berlangsung selama jam pelajaran.

Dari hasil observasi yang penulis lakukan di kelas VI dengan pengajaran yang disampaikan oleh guru Bahasa Arab dimana poses belajar mengajar didalam kelas berjalan sama dan yang membedakannya adalah ruangan kelasnya. Dalam arti cara penyampaian atau metode yang dipergunakan tidak berbeda dengan apa yang di sampaikan dikelas lainnya. Selain itu, guru juga membuat kelompok diskusi sesuai dengan tema pelajaran pada saat pembelajaran bahasa Arab.

Berikut proses yang ditetapkan saat belajar mengajar guru bahasa Arab :

1. Pada awalnya guru masuk ke kelas kemudian mengucap salam

2. Kemudian menanyakan kabar siswa

3. Setelah itu guru menyuruh siswa untuk membuka buku paket masing-masing sesuai dengan bab yang akan dipelajari

4. Kemudian guru menuliskan apa yang dipelajari di buku di papan tulis

5. Setelah itu guru membaca apa yang sudah di tulis di papan kemudian siswa di minta untuk mengikuti

6. Kemudian guru menyuruh siswa untuk membaca tanpa melihat apa yang ditulis di papan tulis

7. Setelah itu, guru menyuruh siswa menghafalkan apa yang sudah di tulis dan di baca dan siswa di berikan waktu 5 menit.

8. Kemudian guru menyuruh siswa untuk mengerjakan latihan yang ada di buku paket bahasa Arab

9. Setelah siswa sudah mengerjakan latihan, guru memeriksa hasil latihan yang sudah di kerjakan oleh siswa.

10. Kemudian untuk siswa yang sudah mengerjakan dan diperiksa latihannya boleh keluar dari kelas

Jadi seorang guru sangat berperan dalam sebuah proses belajar mengajar karena seorang guru tidak hanya memberikan materi saja melainkan guru membimbing dan mengarahkan siswa untuk belajar aktif. Dan dengan belajar aktif, siswa akan bergairah dalam belajar., sehingga minat dan gairah mereka semakin besar karena keaktifan mereka dalam mengikuti pembelajaran. dan selain itu guru bahasa arab juga harus kreatif dan aktif sehingga pelajaran yang akan di sampaikan bisa diterima oleh siswa.

Penulis juga berhasil mewawancarai beberapa siswa terkait dengan peran guru dalam menerapkan metode eklektikpada pembelajaran bahasa Arab :

1. Danya mengatakan bahwa belajar bahasa Arab itu menyenangkan apalagi ustadz yang mengajarkan baik dan tidak cepat marah, selain itu, ustadz sering memberikan motivasi dan kisah-kisah lucu selesai belajar makanya, saya senang belajar dan di ajar oleh ustadz. Salsa mengatakan bahwasaya senang belajar bahasa Arab karena ustad yang mengajar bahasa Arab suka bercanda.

2. Granita juga mengatakan bahwa belajar bahasa arab itu sulit, susah menghafal mufradatnya dan saya suka lupa tapi saya seneng di ajar bahasa Arab sama ustadz karena beliau tidak cepat marah kalau saya tidak bisa dan suka becanda juga. Alia 
juga mengatakan bahwa saya suka belajar bahasa Arab dan seneng di ajar sama ustadz karena cara mengajar ustadz menyenangkan sehingga saya cepat mengerti.

Dari hasil wawancara dengan siswa tersebut dapat disimpulkan bahwaperan guru sangat penting dalam menerapkan metode yang akan di gunakan dalam proses belajar mengajar di kelas walaupun mulanya siswa tidak tertarik untuk belajar bahasa Arab akan tetapi karena guru pintar dan kreatif dalam menggunakan metode akhirnya siswa akan menjadi tertarik untuk belajar bahasa Arab.

Metode merupakan faktor pendukung keberhasilan dalam pembelajaran Bahasa Arab. Di samping itu juga kita tidak bisa menyampaikan faktor-faktor yang lain yang juga kita dapat mendukung terhadap keberhasilan pembelajaran Bahasa Arab. Dalam memilih metode, yang perlu dipertimbangkan tujuan yang ingin disampaikan dan semuannya itu sangat mendukung dalam proses belajar mengajar, baik tidaknya, berhasil tidaknya suatu metode tergantung sesuai tidaknya materi yang disampaikan dengan fasilitas-fasilitas yang tersedia.

Metode yang diterapkan di SDIT dalam pembelajaran bahasa Arab adalah metode eklektik, yang mana yang dimaksud metode disini adalah cara yang digunakan oleh seorang guru untuk membimbing dan mengarahkan siswa dan siswinya untuk tidak terfokus sama satu metode saja akan tetapi menggunakan banyak metode. Dan dengan menggunakan banyak metode guru bahasa Arab akan mudah melihat minat siswa itu, untuk belajar bahasa Arab dan dengan menggunakan banyak metode, siswa tidak akan cepat bosan untuk belajar bahasa Arab.

Sebagaimana menurut (Acef Hermawan) metode eklektik adalah metode yang merupakan pemilihan dan penggabungan. pemilihan dan penggabungan yang di maksud metode ini bukan menggabungkan metode yang ada, tetapi lebih bersifat “ tambal sulam" artinya setiap metode dipandang dapat mengatasi kekurangan metode tertentu dengan memanfaatkan kelebihan metode lain. Metode ini adalah metode yang menggabungkan beberapa metode sesuai kebutuhan atas dasar pertimbangan tujuan pembelajaran, sifat materi pelajaran, kemampuan pelajar, bahkan kondisi guru.

Dengan metode campuran ini guru akan lebih mudah dalam memberikan materi pelajaran kepada siswa karena di SDIT sudah memiliki buku paket sendiri jadi siswa dapat belajar dengan mudah dan yang mendesain buku tersebut adalah guru atau ustadz yang mengajar bahasa Arab di kelas VI, jadi siswa lebih mudah untuk belajar sendiri dirumah.

Menurut guru bidang study Bahasa Arab dalam wawancaranya adalah Dalam proses belajar mengajar saya tidak menggunakan satu metode namun saya menggunakan berbagai macam metode karena kalau saya menggunakan hanya satu metode, siswa akan cepat merasa bosan dan jenuh untuk belajar, apalagi mereka masih berada di bangku SD dan oleh karena itu saya menggunakan dan memilih metode eklektik sebagai metode saya dalam proses belajar mengajar dikelas.

Berdasarkan hasil observasi peneliti dalam setiap pembelajaran di kelas VI SDIT Anak Sholeh Mataram, bahwa dalam proses belajar mengajar guru tidak menerapkan satu metode saja akan tetapi, guru menerapkan banyak metode untuk memudahkan siswa dalam belajar dan guru juga menggunakan pendekatan dalam mengajar di kelas. Pendekatan yang di pakai oleh guru di dalam kelas adalah pendekatan yang bervariasi. Dengan metode yang bervariasi ini, kegiatan belajar mengajar akan lebih mudah, lebih efektif dan efisien. 
Metode yang bervariasi yang digunakan oleh guru sangat membantu dalam meningkatkan minat belajar siswa, karena pada hakikatnya metode yang bervariasi ini merupakan salah satu upaya dan strategi dalam mengatasi kesulitan guru dalam mengatasi kesulitan yang dihadapi siswa. Dengan metode yang bervariasi yang digunakan oleh guru bahasa Arab yang ada di kelas VI SDIT Anak Sholeh Mataram akan memberikan sumbangan yang cukup strategis dalam meningkatkan proses proses belajar mengajar yang efektif.

Di SDIT Anak Sholeh Mataram juga menekankan 4 keterampilan pada buku paket untuk pembelajaran bahasa Arab, akan tetapi guru bahasa Arab mengambil 3 saja dari keterampilan yang 4 itu, dan tiga keterampilan yang dipakai yaitu keterampilan mendengarkan, menulis, dan membaca. Di sini guru hanya menekankan 3 keterampilan saja karena guru melihat dari kemampuan siswa dan kondisinya, keterampilan berbicara tidak di tekankan pada buku paket ini karena guru melihat siswa masih belum mampu untuk belajar berbicara apalagi siswa yang belajar masih di bangku SD oleh karena itu, guru tidak memasukkan keterampilan berbicara dalam proses belajar bahasa Arab pada siswa khususnya kelas VI di SDIT Anak Sholeh Mataram. Selain itu juga guru bahasa Arab memberikan kebebasan kepada siswa untuk belajar dimana saja yang penting siswa tidak jauh dari kelas dan yang penting siswa mau belajar.Selain itu, guru bahasa Arab juga mengatakan bahwa saya tidak harus menyuruh siswa untuk belajar didalam kelas saja tetapi saya memberikan siswa belajar dimana saja asalkan mereka mau belajar.

Sesuai dengan hasil penulis setelah mengadakan penelitian dengan menggunakan data-data yang diperlukan sesuai dengan rumusan masalah yang penulis angkat, maka setelah mengadakan pengolahan data dengan menjadikan SDIT Anak Sholeh Mataram sebagai lokasi penelitian. Adapun hasil-hasil yang penulis maksudkan untuk dibahas dalam bab pembahasan ini adalah sebagai berikut:

\section{Penerapan Metode Eklektik Pada Pembelajaran Bahasa Arab Siswa Kelas VI SDIT Anak Sholeh Mataram.}

Guru merupakan orang yang bertanggung jawab dalam proses belajar mengajar di kelas, selain itu, guru juga bertugas mendidik, membimbing, mengarahkan dan memberikan dorongan kepada siswa untuk semangat dalam belajar.

Mengajar merupakan suatu proses yang kompleks, tidak hanya sekedar menyampaikan informasi dari guru kepada siswa. Setiap guru memiliki pola mengajar sendiri-sendiri. Pola mengajar itu tercermin dalam tingkah laku pada waktu melaksanakan kegiatan proses belajar mengajar.

Setiap guru diharapkan untuk meningkatkan pengajarannya secara efektif. Di masyarakat modern, pengajaran efektif dituntut dengan sendirinnya kepada pengajar karena perkembangan ilmu pengetahuan dan tekhnologi untuk meningkatkan mengajar supaya efektif, itulah konsekwensi guru dalam menanggapi pembaharuan dalam dunia pengajaran.

Berdasarkan hasil observasi awal yang dilakukan peneliti, dalam proses pembelajaran yang selama ini diterapkan oleh guru di SDIT Anak Sholeh Mataram, dalam menyampaikan materi ajar pada mata pelajaran bahasa Arab di kelas VI yaitu sebagai berikut : 
1. Guru menuliskan materi di papan tulis kemudian menjelaskan materi dan peserta didik membaca materi yang akan diajarkan, sehinga peserta didik cepat menanggapi dan memahami penjelasan dari guru.

2. Peserta Didik diberikan waktu untuk menghapal materi yang sudah dijelaskan selama dua menit dan peserta didik dipanggil satu persatu sesuai urutan absen untuk menghapal materi yang sudah dijelaskan.

3. Guru melakukan tanya jawab dan memberikan soal atau latihan kepada peserta didik dan yang dinilai dalam soal latihan itu adalah tulisan, kerapian dan ketepatan hurufnya kemudian setelah itu, guru memberikan peserta didik stimulus dengan membuat pertanyaan dan peserta didik menjawabnya.

4. Kemudian guru menceritakan kisah yang bernuansa Islami dan ada humornya untuk menyegarkan kepala peserta didik dan guru juga menyelipkan pesan-pesan moral kepada peserta didik.

Dan dari pemaparan diatas peneliti dapat menarik kesimpulan bahwa metode yang digunakan guru Bahasa Arab diatas tadi adalah metode eklektik. Dan guru memilih menggunakan metode eklektik karena guru merasa metode inilah yang paling tepat untuk digunakan, apalagi peserta didik yang diajarkan masih pada tingkat pemula dan guru juga merasa bahwa dengan menggunakan metode ini akan membuat peserta didik akan belajar lebih menyenangkan karena kalau guru hanya memakai satu metode saja, apalagi siswa dan siswi yang diajarkan masih pada tingkat pemula, otomatis peserta didik akan merasa bosan dalam belajar Bahasa Arab.

Dan penulis juga berhasil mewawancarai beberapa siswa terkait dengan peran guru dalam menerapkan metode eklektik pada pembelajaran bahasa Arab. Danya mengatakan bahwa belajar bahasa Arab itu menyenangkan apalagi ustadz yang mengajarkan baik dan tidak cepat marah, selain itu, ustadz sering memberikan motivasi dan kisah-kisah lucu selesai belajar makanya, saya senang belajar dan di ajar oleh ustadz.

Salsa mengatakan bahwa saya senang belajar bahasa Arab karena ustad yang mengajar bahasa Arab suka bercanda. Granita juga mengatakan bahwa belajar bahasa arab itu sulit, susah menghafal mufradatnya dan saya suka lupa tapi saya seneng di ajar bahasa Arab sama ustadz karena beliau tidak cepat marah kalau saya tidak bisa dan suka becanda juga.

Dari hasil wawancara dengan siswa tersebut dapat disimpulkan bahwa peran guru sangat penting dalam menerapkan metode yang akan di gunakan dalam proses belajar mengajar di kelas walaupun mulanya siswa tidak tertarik untuk belajar bahasa Arab akan tetapi karena guru pintar dan kreatif dalam menggunakan metode akhirnya siswa akan menjadi tertarik untuk belajar bahasa Arab.

Berdasarkan paparan data dan hasil temuan penelitian yang penulis peroleh dari lokasi penelitian bahwa proses pembelajaran Bahasa Arab di kelas VI SDIT Anak Sholeh Mataram sudah efektif karena siswa yang sekolah di sini merupakan siswa yang aktif-aktif dalam mengikuti pembelajaran khususnya bahasa Arab itu sendiri.

Berdasarkan hasil observasi penulis selama meneliti di SDIT Anak Sholeh Mataram dan adapun langkah-langkah seorang guru dalam mengajar bahasa Arab di kelas VI SDIT Anak Sholeh Mataram antara lain:

1. Mengucapkan salam

2. Menanyakan kabar dan materi

3. Memberikan motivasi / kisah-kisah islami 
4. Klasikal(guru mencontohkan dan memperagakan materi hiwar)

5. Siswa meniru percakapan (di ulang-ulang bersama-sama)

6. Menunjuk siswa untuk mencoba (individual)

7. Melakukan dialog berpasangan dan bergantian (maju ke depan kelas)

8. Evaluasi kegiatan belajar dan saran-saran untuk siswa

9. Menutup pembelajaran dan mengakhiri dengan sala.

\section{Penerapan Metode Eklektik Pada Pembelajaran Bahasa Arab Siswa Kelas VI SDIT Anak Sholeh Mataram}

Penerapan metode eklektik ini, membangun watak dan kepribadiannya muridmuridnya. Dihubungkan dengan fenomena yang timbul di dalam kelas dimana guru semakin disenangi, disegani dan dihormati oleh peserta didik. Untuk memilih metode yang tepat dalam mendidik peserta didiknya adalah dengan menyesuaikan metode dengan kondisi psikis peserta didiknya. Ia harus mengusahakan agar meteri pelajaran yang diberikan kepada peserta didik mudah diterima.

Pelaksanaan pembelajaran bahasa Arab di SDIT Anak Sholeh Mataram yang berpedoman pada buku-buku pelajaran yang bersumber dari departemen agama dan modul yang disusun oleh guru yang berorientasi kepada penguasaaan keterampilan dalam berbahasa yaitu keterampilan mendengarkan, membaca, menulis, dan berbicara. keempat keeterampilan tersebut merupakan tujuan dari pembelajaran bahasa Arab.

Untuk memperlancar pelaksanaan pembelajaran guru memerlukan suatu metode atau cara dalam mencapai tujuan pembelajaran yang telah ditetapkan. Metode mengajar merupakan sarana interaksi guru dengan siswa dalam pelaksanaan pembelajaran. Untuk itu agar interaksi yang terjadi antara guru dengan siswa berjalan dengan baik, maka guru menggunakan metode mengajar yang vareatif yang disesuaikan dengan tujuan, jenis dan materi yang diajarkan.

Maka dalam proses belajar mengajar, meode pendidikan merupakan salah satu aspek pendidikan yang sangat penting guna mentransfer pengetahuan atau kebudayaan dari seorang guru kepada muridnya. Melalui metode pengajaran terjadi proses internalisasi dan pemikiran pengetahuan oleh murid hinga murid dapat menyerap dan memahami dengan baik apa yang telah disampaikan gurunya.

Oleh karena itu setiap metode mempunyai ciri dan kegunaannya secara khusus, seseorang guru tidak cukup hanya dengan mengetahui berbagai metode dan pengunaannya. Ia harus menguasai pula setiap metode itu dengan unsur-unsur lainya dalam proses belajar mengajar

Dalam pelaksanaan kegiatan belajar mengajar pada mata pelajaran bahasa arab di SDIT Anak Sholeh Mataram, guru menggunakan beberapa metode mengajar, yaitu:

1. Metode ceramah

2. Metode tanya jawab

3. Metode kerja kelompok

4. Metode Pemberian Tugas

\section{Kesimpulan}


Berdasarkan pembahasan data pada bab III, maka dapat ditarik suatu kesimpulan tentang peran guru dalam menerapkan metode eklektik pada pembelajaran bahasa Arab sebagai berikut:

1. Peran guru dalam menerapkan metode eklektik pada pembelajaran bahasa arab, guru tidak hanya sekedar menyampaikan materi pelajaran, akan tetapi lebih mengarah kepada peran untuk mendidik, membimbing dan mengarahkan siswa kepada sistem pembelajaran yang aktif sehingga siswa tidak menerima dari guru saja akan tetapi siswa ikut terlibat dalam proses belajar itu sendiri.

2. Metode yang digunakan guru bahasa Arab di kelas VI SDIT Anak Sholeh Mataram adalah metode eklektikyaitu guru mengkombinasikan antara metode mubasyarah dengan metod aural oral approach.

\section{Saran-saran :}

Berdasarkan sejumlah temuan yang diperoleh dalam penelitian ini ada beberapa yang bisa dijadikan saran bagi siswa, sekolah maupun lembaga yang terkait yaitu:

1. Bagi lembaga/sekolah

a. Bagi sekolah hendaknya menambah penyediaan sarana yang memadai untuk belajar dan mempraktekkan bahasa Arab di lingkungan madrasah.

b. Bagi kepala sekolah agar selalu mendorong para guru untuk meningkatkan kualitas proses belajar mengajar melalui peningkatan kemampuan dalam menggunakan metode-metode mengajar, sehingga prestasi maupun motivasi belajar secara kuantitatif maupun kualitatif dapat ditingkatkan.

c. Kepada guru khususnya guru bidang studi bahasa Arab hendaknyalebih banyak memperhatikan dalam memilih dan menggunakan metode yang tepat untuk menarik minat siswa untuk mempelajari bahasa Arab.

2. Bagi siswa-siswi:

a. Tempatkanlah bahasa Arab itu seperti bahasa asing yang lain sehingga kalian lebih mudah untuk mempelajarinya dan perbanyaklah untuk menghafal kosakata agar apa yang sudah dipelajari bisa ingat.

b. Hendaknya siswa menganggap bahwa belajar bahasa Arab itu mudah agar minat untuk belajar dan bisa bahasa Arab semakin besar.

c. Hendaknya apa yang sudah dipelajari di sekolah di ulang kembali di rumah agar pelajaran tetap di ingat.

\section{DAFTAR PUSTAKA}

Arikunto, suharsimi, 2002,Prosedur Penelitian. Jakarta: Rineka Cipta.

Arikunto, suharsimi, 2006,Prosedur Penelitian Suatu Pendekatan Praktik. Jakarta: PT. Rineka Cipta.

Arsyad, Azhar, 2003,Bahasa Arab dan Beberapa Metode Pengajarannya. Yogyakarta: Pustaka Belajar.

B. Uno, Hamzah,2011,Profesi Kependidikan. Jakarta: PT. Bumi Aksara.

Depag RI, 2007,Al-Qur'an dan Terjemahanya. Bogor: SYGMA.

Effendi, Fuad, 2005, Ahmad. Metodologi Pengajaran Bahasa Arab. Malang: Miskat. 
Emzir, 2010,Metodologi Kualitatif Analisis Data. Jakarta: PT. Raja Grafindo Persada.

Hamalik, Oemar, 2010,Psikologi Belajar Dan Mengajar. Bandung: Sinar Baru Algesindo.

Hamalik, Oemar, 2001,Proses Belajar Mengajar. Bandung: PT. Bumi Aksara.

Hermawan, Acef, 2011Metodologi Pembelajaran Bahasa Arab. Bandung: PT. Remaja Rosdakarya.

Maimun, 2011,Menjadi Guru Yang Dirindukan. Jogjakarta: PT. Kurnia Alam Semesta.

Mulyasa, 2010,Menjadi Guru Profesional. Jakarta: Remaja Rosdakarya.

Nurdin, Muhammad, 2010Kiat Menjadi Guru Profesional. Jogjakarta: Ar-Ruzz Media.

Sardiman, 2011, Interaksi dan Motivasi Belajar Mengajar. Jakarta: PT. Raja Grafindo Persada.

Sugiono, 2011,Metode Penelitian Kuantitatif Kualitataif dan R \& D. Bandung: AlFabeta.

Soetopo, Hendyat dan Soemanto, Wasty, 1986,Pembinaan dan Pengembangan Kurikulum. Jakarta: Bina Aksara.. 